Research Article

\title{
Survey of Rice Pests, Diseases and Natural Enemies on "Upsus" Program in Karawang District, West Java Province
}

\author{
Kurniawan Effendi 1)*, Abdul Munif ${ }^{1)}$, \& I Wayan Winasa ${ }^{1)}$ \\ ${ }^{1)}$ Department of Plant Protection, Faculty of Agriculture, IPB University \\ Jln. Meranti, Kampus IPB Dramaga, Bogor, West Java 16680 Indonesia \\ *Corresponding author. E-mail: andieffendi212@gmail.com
}

Received October 15, 2019; revised December 21, 2019; accepted March 27, 2020

\begin{abstract}
"Upsus" (Special Efforts) Program is a program to increase crop production and productivity to support the acceleration of food self-sufficiency held by the government. The targets are to increase the planting index (IP) by 0.5 and productivity by 0.3 ton/ha/Harvested Dry Grain. Increased productivity has not been reached optimally. This research aimed to determine the number/types of the dominant pests and natural enemies, and pests and diseases attack rates in the wetland rice plantation "Upsus" Program in Karawang District. Direct observation was carried out on 4 stages of plant development, in the nursery stage (10-14 days after sowing) 200-300 m², seedlings stage (10-20 days after planting), vegetative stage (5-6 weeks after planting), and reproductive stage (1-2 weeks after flowering) respectively within an area of $2000 \mathrm{~m}^{2}$. Twenty samples were observed in the nursery stage and 50 samples in the following stages. The dominant pests and diseases found were Nilaparvata lugens, Leptocarisa oratorius, Schirpophaga incertulas, Cnaphalocrocis medinalis, Scotinophara coarctata, Mythimna separata, bacterial leaf blight (Xanthomonas. oryzae pv. oryzae), blast (Pyricularia grisea) and narrow brown spot (Cercospora oryzae). The recorded dominant natural enemies were Cyrtorhinus sp., Paederus sp., Tetragnatha sp., and Pardosa pseudoannulata. S. incertulas showed the highest attack intensity and the highest disease severity was found in bacterial leaf blight. The largest population of dominant pests and natural enemies was found in the generative stage. The high application of pesticides affected the population of pests, natural enemies, and the level of pest and disease attacks.
\end{abstract}

Keywords: diseases; natural enemies; pests; special effort

\section{INTRODUCTION}

One of the Indonesian government's efforts to increase the production and productivity of food crops is by the implementation of the Special Effort ("Upsus") program. The "Upsus" Program is a government program aims to increase the production and productivity of wetland rice to achieve food self-sufficiency acceleration. The target of "Upsus" in realizing sustainable self-sufficiency is increasing planting index (IP) to 0.5 minimum and increasing rice productivity to 0.3 ton/ha/Harvested Dry Grain. In 2015 , the productivity of rice plantation only reached 55.08 quintal/ha. Yet in 2016 and 2017, the productivity decreased by 53.97 quintal/ha and 53.19 quintal/ha, respectively (Kementerian Pertanian, 2017). This reduction revealed that the "Upsus" target has not been reached optimally.

One that causes a decrease in the productivity of wetland rice plantation is pests and diseases. The dominant pests in wetland rice plantation are brown planthopper (Nilaparvata lugens), rice bug (Leptocorisa oratorius), yellow rice stem borer (Scirpophaga incerculas), rice black bug (Scotinophara coarctata), rice leafroller (Cnaphalocrosis medinalis), armyworm (Mythimna separata) and ricefield rat (Rattus argentiventer Rob. \& Kloss) (Afifah 2019). Dominant diseases in lowland rice are blast (Pyricularia grisea), narrow brown spot (Cercospora oryzae), and bacterial leaf blight (Xanthomonas oryzae pv. oryzae) (Semangun 2008). The existence of natural enemies in rice plants can suppress the pest population. The types of dominant natural enemies in wetland rice are Paederus sp., Cyrtorhinus sp., Tetragnatha sp., and Pardosa pseudoannulata (Badan Penelitian dan Pengembangan Pertanian, 2012).

The general basis to control pests and diseasesis by utilizing conventional pesticides. However unwise conventional pesticide usage could lead to resistance, resurgence, and other environmental problems. Pest and disease control efforts in the "Upsus" program 
should refer to the Integrated Pest Management (IPM) concept that is the use of conventional pesticides as the last effort if pests and diseases have exceeded the economic threshold (Kementerian Pertanian, 2015). As known that pest and disease attackleads to high losses, it is necessary to conduct a research to determine the number/types of pests and dominant natural enemies, the intensity attacks of dominant pest and the severity of dominant diseases in the nursery, seedling stage, vegetative stage and generative stage in the "Upsus" program wetland rice in Karawang Regency, West Java.

\section{MATERIALS AND METHODS}

\section{Location and time}

The survey was conducted at Tempuran and Tirtajaya Districts, Karawang Regency, West Java Province. Locations were chosen based onthe range of wetland areas per district, where wetland in Tempuran and Tirtajaya are 5.000 ha larger than other districts. Rice planting at Karawang Regency refers to the rotation of the water group. Karawang Regency has 3 water groups: group 1, group 2, and group 3. Planting time in water group 1 is in October/November, water group 2 in November/ December, and water group 3 in December/January. Groups differ within 2-6 weeks (Priyonugroho, 2014). Tempuran and Tirtajaya Districts are in water groups 2 and 3, hence the survey was conducted in October 2018-April 2019 or adjusted to the rotation of the water group.

\section{Initial survey}

The initial survey was aimed to determine and select the wetland area in "Upsus" areas, at Tempuran and Tirtajaya Districts, where the assessment was performed. Assessment areas were selected randomly inconsidering near the main road, spread in one district area, and were or had carried out the "Upsus" program. Assessment areas were also the area under "Upsus" program.

\section{Direct assessment}

Surveys of pests, natural enemies, and diseases in "Upsus" wetland rice were conducted by direct observation of the number and types of pests and major natural enemies, the intensity of pest attacks, and the severity of the disease. The direct assessment was done in 12 locations (6 locations in Tempuran District and 6 locations in Tirtajaya District). Observation using the diagonal method and on 4 stages of growth. In the nursery, the direct assessment was conducted on 20 shoots age 10-14 days old in 200-300 $\mathrm{m}^{2}$ plot. A seedling assessment was made when the plant age 10-20 days after planting (dap), in the vegetative stage at 5-6 weeks after planting (wap) and in the generative stage at 1-2 weeks after flowering (waf). The observed samples were 50 clumps/plant in the $2.000 \mathrm{~m}^{2}$ for seedling, vegetative, and generative stages. Each sample of plants was observed the number/type of pests and natural enemies, symptoms of the pest attack, and the disease symptoms. Symptoms of pests lead to the intensity of pests and disease attack symptoms lead to disease severity. The assessment was held at 06.00-08.00 a.m. Direct observation was deliberately done in the morning because during the day pests and natural enemies tend to take shelter to avoid the sun rays.

The direct assessment produces data on the number/types of pests and major natural enemies, the intensity of dominant pest attack, and the severity of major diseases. Types of pests discovered and determined its population density were brown planthopper, rice black bug, armyworms, rice bug, and yellow rice stem borer along with the yellow rice stem borer eggs. The majornatural enemies found were Paederus sp., Cyrtorhinus sp., Tetragnatha sp., and Lycosa pseudoannulata. Observing natural enemies weremore focused on planthopper natural enemies, insect borer, and rice leafroller hence other than this were not observed further. Population density of pests and natural enemies was the total number of each type of pest or natural enemy found divided by the total number of shoot/clump observed.

The intensity of the pest attack could be determined from samples of wetland rice plants affected by the attack or the pest attack symptoms. Symptoms of each type of pests have special traits that easily distinguished. Types of pests that calculated the attack intensity are yellow rice stem borer, rice leafroller, armyworm, and ricefield rat. The intensity of pest attacks of rice leafroller, and armyworm calculated using the formula (Dewi, 2002 cit Maulana et al., 2017):

$$
\mathrm{I}=\frac{\mathrm{n} \times 100 \%}{\mathrm{~N}}
$$


I : The intensity of pest attack (\%)

$\mathrm{n} \quad$ : Number of plants/samples attacked

$\mathrm{N}$ : Number of plants/sample observed

The intensity of the ricefield rat and yellow rice stem borer was calculated using the formula (Priyambodo, 2003 cit. Sipayung et al., 2018):

$$
I=\frac{a}{a+b} \times 100 \%
$$

I: The intensity of ricefield rat attack (\%)

a: Number of tillers/samples attacked

b: Number of tillers/samples that were not attacked

Only the major diseases that were counted the severity index. The severity of the disease was calculated using formula (Ginting, 2003 cit. Aprizal, 2018):

$$
D S=\frac{\sum(\mathrm{n} \times \mathrm{v})}{N \times V} \times 100 \%
$$

$$
\begin{array}{ll}
\mathrm{DS} & : \text { Disease severity (\%) } \\
\mathrm{N} & : \text { Number of samples/plants observed } \\
\mathrm{n} & : \text { Number of samples/plants attacked } \\
\mathrm{V} & : \text { Highest scale } \\
\mathrm{V} & \text { : Attack category }
\end{array}
$$

Bacterial leaf blight (Table 1), blasts (Table 2) and narrow brown spot (Table 3) scoring were referring to the Standard Evaluation System (SES) guidelines for Rice (IRRI, 2014). Data were analyzed using the average test of two populations with $\alpha=0.05$ then

\begin{tabular}{|c|c|}
\hline Score & Description \\
\hline 1 & Symptoms $<1 \%$ in one clump \\
\hline 3 & Symptoms $1-5 \%$ in one clump \\
\hline 5 & Symptoms $6-25 \%$ in one clump \\
\hline 7 & Symptoms $26-50 \%$ in one clump \\
\hline 9 & Symptoms $51-100 \%$ in one clump \\
\hline
\end{tabular}
presented in tabular form in Office 2013.

Table 1. Scoring of bacterial leaf blight

\begin{tabular}{cl}
\hline Score & Description \\
\cline { 1 - 1 } 0 & No symptoms of the disease \\
1 & Symptoms of 1-5\% in one clump \\
3 & Symptoms of $6-12 \%$ in one clump \\
5 & Symptoms of $13-25 \%$ in one clump \\
7 & Symptoms of $26-50 \%$ in one clump \\
9 & Symptoms of $50-100 \%$ in one clump \\
\hline
\end{tabular}

Table 2. Scoring of blast disease

\begin{tabular}{cll}
\cline { 1 - 1 } Score & Description \\
\cline { 1 - 1 } 0 & & No symptoms of the disease \\
1 & Symptoms are not clear yet \\
2 & Symptoms of $<5 \%$ in one clump \\
3 & Symptoms $\geq 5 \%-<25 \%$ in one clump \\
4 & Symptoms $\geq 25 \%-<50 \%$ in one clump \\
5 & Symptoms $\geq 50 \%$ in one clump \\
\hline
\end{tabular}

Table 3. Scoring of narrow brown spot disease

\section{RESULTS AND DISCUSSION}

\section{Wetland Rice Plantation Cultivation with "Upsus" Program Implementation}

The main performer of the "Upsus" program isa group of farmers who are members of an active farmer, have a unified wetland rice plantation, able to carry out a whole series of "Upsus" implementation stages, have a clear farmer groups management, have an active bank account and was willing to make a capability statement of using grants according to its purpose (Direktorat Jenderal Tanaman Pangan, 2015). The stages of the "Upsus" program start with the preparation of the Group Definitive Needs Plan (GDNP), disbursement of aid funds (purchase of production facilities, assistance with planting costs, and meeting cost 4 times), purchase of production facility packages (excellent varieties, subsidized fertilizers, and pesticides), use of excellent varieties, the right time ofplanting, balanced fertilization, effective water supply, crop protection and harvest/ post-harvest handling (Kementerian Pertanian, 2015).

The Group Definitive Needs Plan (GDNP) is a plan for the needs of agricultural production facilities and agricultural tools/machines in one cycle based on the group discussion. GDNP is an absolute requirement for obtaining agricultural production facilities, including agricultural equipment and machinery as well as planning for the need for subsidized fertilizer (Direktorat Pupuk dan Pestisida, 2014). The preparation of the GDNP must involve Agricultural Extension Worker and all management and members of farmer groups.

The cropping pattern adopted by "Upsus" farmers is jajar legowo. "Upsus" recommended the application of 2:1 and 4:1 legowo row. Legowo row of 2:1 has $(20 \mathrm{~cm}-40 \mathrm{~cm}) \times 10 \mathrm{~cm},(25 \mathrm{~cm}-50 \mathrm{~cm}) \times 12.5 \mathrm{~cm}$ and $(30 \mathrm{~cm}-60 \mathrm{~cm}) \times 15 \mathrm{~cm}$ spacing, and the $4: 1$ has $(20 \mathrm{~cm}-40 \mathrm{~cm}) \times 10 \mathrm{~cm}$ and $(25 \mathrm{~cm}-50 \mathrm{~cm}) \times 12.5 \mathrm{~cm}$ spacing (Direktorat Jenderal Tanaman Pangan, 2015). 
The cropping pattern and planting distance applied are following the recommendations of the "Upsus" program. The "Upsus" Program required excellent certified varieties released by the Minister of Agriculture, have a minimum growth capacity of $80 \%$, maximum moisture content of $13 \%$, and a seed impurities maximum of $2 \%$ (Kementerian Pertanian, 2015). The varieties used by farmers are following "Upsus's" recommendations. At Tempuran District, most farmers use Ciherang variety and at Tirtajaya District, most farmers use Inpari 32 variety. Ciherang variety is resistant to brown planthopper biotype 2, moderately resistant to brown leafhopper biotype 3 , and resistant to bacterial leaf blight strain III and IV. Inpari 32 variety is resistant to bacterial leaf blight strain III, moderately resistant to bacterial leaf blight strain IV, resistant to blast race 0.33 , moderately resistant to tungro, and moderately susceptible to brown planthopper biotypes 1, 2 and 3 (Badan Penelitian dan Pengembangan Pertanian, 2009).

Upsus farmers have implemented simultaneous planting following "Upsus's" recommendations. The type of fertilizer used most farmers at Tempuran District is urea and TSP, while at District Tirtajaya, most farmers use urea, TSP, and NPK. Farmers fertilize two times/planting seasons. The intensity of fertilizer application should be done 3 times, i.e.0-14 dap, 21-28 dap, and 35-50 dap (IRRI, 2005). Farmers at the District Tempuran assumed that N, P, and $\mathrm{K}$ nutrients were already supplied from urea and TSP, hence NPK no longer required. Single fertilizer application should refer to the content of $\mathrm{N}, \mathrm{P}$, and $\mathrm{K}$ nutrient in a balanced approach, not only the $\mathrm{N}$ and $\mathrm{P}$ nutrient. There is a variation understanding among farmers in implementing balanced fertilization. Some farmers consider that balanced fertilization is identical to the use of compound fertilizer. In certain locations, the use of compound fertilizer might follow the concept of balanced fertilization but in other locations, it could cause waste because the compound fertilizer nutrient formulations are not following the needs of the plant.

Pest and disease control in the "Upsus" program refer to the concept of Integrated Pest Management (IPM) where the use of conventional pesticides as thelast effort if the pest and disease attacks have exceeded the economic threshold. Harvest and postharvest handling in the "Upsus" program include the right time of harvesting, product storage, and prevention of pests and diseases in the storage warehouse (Kementerian Pertanian, 2015). Most of the "Upsus" farmers have carried out the "Upsus" program stages as recommended, except for pest and disease control. To control pests and diseases, "Upsus" farmers still refer to the annual basis from the previous planting season and have not yet referred to the IPM concept recommended by Upsus.

\section{Major Pests on "Upsus" Wetland Rice}

The major pests found were brown planthopper (N. lugens), rice bug (L. oratorius), yellow rice stem borer (S. incertulas), rice black bug ( $S$. coarctata), rice leafroller ( $C$. medinalis), armyworm $(M$. separata), and ricefield rat ( $R$. argentiventer). Each pest has a varying population density. Not all pests can be found in every stage of rice plant growth. The largest pest population was found in the generative stage.

Brown Planthopper. N. lugens is a major pest in wetland rice, feeding sap of the plant tissues and cause mild to severe damage. The symptoms of $N$. lugens attack are yellowing and dry leaves (hopperburn). Hopperburn initially forms a circle that shows the pattern of spread of $N$. lugens which starts from a single point, then spreads in all directions in the circle shape. In such circumstances, the brown planthopper population is generally already very high (Putra, 2018). N. lugens population was found at Tempuran District relatively low: 0.52 individual/shoot in the nursery, 0.18 individual/ clump inthe seedling stage, 0.45 individual/clump in the vegetative stage, and 0.64 individual/clump in generative stage (Table 4). The largest population density was in the generative stage. At Tirtajaya District, brown planthopper population density reached 0.66 individual/shoot in the nursery, 0.25 individual/clump in the seedling stage, 0.37 individual/ clump in the vegetative stage, and 0.60 individual/ clump in the generative stage (Table 4). The largest population density was in the nursery. $N$. lugens population density was low and below the economic threshold. The control of $N$. lugens needs to be conducted when 3 individuals/clumps are found in rice plants less than 40 dap or 5 individuals/clump 
Table 4. The population of pests was found during the growth stage of wetland rice plantation at Tempuran and Tirtajaya District, Karawang, October 2018-April 2019

\begin{tabular}{|c|c|c|c|c|c|c|c|c|c|c|}
\hline \multirow{3}{*}{ District } & \multicolumn{10}{|c|}{ Pest population (individual/sample) in each stage of the growth of wetland rice plantation } \\
\hline & \multirow{2}{*}{$\frac{\text { Nursery }}{\text { WBC }}$} & \multicolumn{2}{|c|}{ Seedling } & \multicolumn{3}{|c|}{ Vegetative } & \multicolumn{4}{|c|}{ Generative } \\
\hline & & WBC & KT & WBC & KT & HPP & WBC & $\overline{\mathrm{UG}}$ & HPP & WS \\
\hline Tempuran & 0.52 & 0.18 & 0.00 & 0.45 & 0.06 & 0.13 & 0.64 & 0.004 & 0.02 & 0.06 \\
\hline Tirtajaya & 0.66 & 0.25 & 0.003 & 0.37 & 0.01 & 0.16 & 0.60 & 0.063 & 0.05 & 0.10 \\
\hline
\end{tabular}

Remarks: $\mathrm{WBC}=$ Brown planthopper, $\mathrm{KT}=$ Rice black bug, $\mathrm{HPP}=$ rice leafroller, $\mathrm{UG}=$ Armyworm, and $\mathrm{WS}=\mathrm{Rice}$ bug. Nursery stage 20 shoots, seedling, vegetative and generative stages 50 clumps.

in rice plants aged more than 40 dap (Baehaki \& Mejaya, 2014). Attacks of 1-4 N. lugens/clump in the nursery reduce yields by $35 \%-77 \%$, during the generative stagereduce yields by $20 \%-37 \%$, while during maturity reduce yields by $28 \%$ (Nurbaeti et al., 2010).

$N$. lugens population density was low due to the presence of natural enemies and conventional insecticides applications. Conventional insecticides were applied by farmers since 7-10 dap. Conventional insecticides used to control brown planthopper generally have active ingredients of acephate, abamectin, cypermethrin, and buprofezin. The intensity of insecticide applied by farmers was more than 10 times/planting season. The use of insecticides overlooks natural enemies and economic thresholds. The insecticide failure was caused by the level of resistance and resurgence of brown planthopper which leads to population increase (Baehaki, 2016). Planting is not simultaneous and unpredictable rainfall affects the rate of $N$. lugens population (Baehaki \& Mejaya, 2014). The existence of $N$. lugens in wetland cultivation was also influenced by the plant variety planted, temperature, humidity, and rainfall (Sianipar, 2018). Water regulations and its quantity and the conventional fertilizer application also affect the development of $N$. lugens population.

Rice Black Bug. S. coarctata is a pest of rice feedssap and causes the stalk to become stunted, leaves turn yellow and die. Symptoms of the damage are the places that pests used to suck fluid will turn to be brown, leaves dry and roll longitudinally (Paendong et al., 2011). S. coarctata population was only found in the seedling and vegetative stages. In the seedling, the population of $S$. coarctata was only at Tirtajaya District $(0.003$ individual/clump). In the vegetative stage was 0.060 individual/clump at Tempuran District and 0.010 individual/clump at Tirtajaya District (Table 4). The population density of $S$. coarctata was relatively low and below the economic threshold. The economic threshold of $S$. coarctata is 6 individual/clump (Heinrichs et al., 1986). The first infestation of $S$. coarctata generally at the age of 2-3 wap and will increase during the rainy season due to the migration of $S$. coarctata. The earlier an infestation of $S$. coarctata in therice cultivation, the higher the level of damage inflicted (Kartohardjono, 2009). The control of $S$. coarctata was not carried out by farmers because they considered the attack rate was still low.

Rice Leafroller. C. medinalis is an important pest of rice with the common symptoms is rolled leaves with larvae inside it. The larvae live in rolled leaves, feed on the leaf tissue, and cause the formation of transparent white lines $(15-20 \mathrm{~cm})$ that interfere with the growth of rice plants (Tangkilisan et al., 2013). C. medinalis adults were only found in the vegetative and generative stage (Table 4). In the vegetative stage, the population of C. medinalis adults found at Tempuran District was 0.130 individual/clump and at Tirtajaya District was 0.160 individual/clump. In the generative stage, at Tampuran District was 0.020 individual/clump and at Tirtajaya District was 0.050 individual/clump (Table 4). The low population of $C$. medinalis was caused by the presence of natural enemies, the intensity of the application of pesticides by farmers on a scheduled basis, farmer cultivation techniques, and weather factors such as humidity, temperature, and rainfall.

Armyworms. M. separata found on the location was identified from the characteristics of the early instar larvae that were light green to slightly dark with a narrow lateral line and the late instar larvae were light to dark gray with a clear lateral line along 
the body. The population of M. separatawas still below the economic threshold. The economic threshold of armyworms was 2 individuals/clump (Kartohardjono, 2009). M. separata population was only found in the generative stage, 0.004 individual/clump at Tempuran District, and 0.063 individual/clump at Tirtajaya District (Table 4). $M$. separata attracted to rice contain high nitrogen (Kartohardjono, 2009). Excessive use of urea may result in high nitrogen content in plantations.

Rice Bug. L. oratorius generally start to infest when the rice entering the generative stage and mature. L. oratorius is a pest that feeds on rice seeds and found only in the generative stage. The population density of L. oratorius found at Tempuran District was 0.06 individual/clump and 0.1 individual/clump at Tirtajaya District (Table 4). The low population density of $L$. oratorius causes no control efforts by farmers. $L$. oratorius adults were generally more found in the observation site than nymphs. The level of attack and decreased yields due to $L$. oratorius adult is greater than nymphs. If there were 5 adults/ 9 clumps, it would reduce yields by $15 \%$ and if there were 10 adults/9 clumps, it would reduce yields up to $25 \%$ (Kartohardjono, 2009).

Yellow Rice Stem Borer. Yellow rice stem borer (S. incertulas) was the type of rice stem borer found at the observation site. The population of $S$. incertulas in the nursery at Tempuran District was 0.200 individual/shoot with egg masses of 0.300 eggs/shoot, in the seedling 0.006 individual/clump and 0.020 eggs/clump, in the vegetative stage was only found egg masses (0.003 eggs/clumps), and in the generative stage was 0.003 individual/ clump and 0.020 eggs/clumps. In Tirtajaya District, the population of $S$. inertias in the nursery was $0.310 \mathrm{individual} / \mathrm{shoot}$ and $0.820 \mathrm{eggs} / \mathrm{shoots}$, in the seedling stage was only found 0.003 individual/clump.
In the vegetative stage was 0.060 individual/clump and egg masses of 0.020 eggs/clump, and in the generative stage was 0.013 individual/clump and 0.013 eggs/clump (Table 5). The largest population of $S$. incertulas and eggs were in the nursery. Because in the nursery, farmers did not use a lot of conventional pesticides.

\section{The Intensity of Pest Attack on "Upsus" Wetland Rice}

Several types of major pests can cause some symptoms that are typical so it can be used as a standard to determine the intensity of the attack. The intensity of pest attacks found at the observation site was yellow rice stem borer, rice leafroller, armyworm, and ricefield rat. The intensity of attacks was generally below the economic threshold, except the intensity of yellow rice stem borer attacks in the seedling stage. The intensity of the yellow rice stem borer attack in Tempuran District in the seedling stage was $12.35 \%$, in the vegetative stage was $5.53 \%$, and in the generative stage was $4.45 \%$. In Tirtajaya District, the intensity of yellow rice stem borer attacks found in the seedling stage was $16.90 \%$, in the vegetative stage was $6.90 \%$ and in the generative stage was $6.25 \%$ (Table 6). The intensity of the yellow rice stem borer attacks in the seedling stage was above the economic threshold.

The economic threshold is adjusted to the price of grain at harvest time hence the economy threshold becomes flexible. The economic threshold of yellow rice stem borer attack in the vegetative stage is $6 \%$ of deadheart symptom for grain price at harvest $\mathrm{Rp} 900.00 / \mathrm{kg}$ while in the generative stageis $9 \%$ of whitehead symptoms for grain price at harvest Rp 900.00/kg. If the price of grain during harvest increases to $\mathrm{Rp} 2,250 / \mathrm{kg}$, the economic threshold for yellow rice stem borer in the vegetative stage is $3 \%$ and in the generative stage is $4 \%$. After 2009 , the economic threshold of insect borer is not based on the intensity of the attack but based on the

Table 5. The yellow rice stem borer adults and eggs were found during the growth stage of wetland rice plantation at Tempuran and Tirtajaya District, Karawang, October 2018-April 2019

\begin{tabular}{|c|c|c|c|c|c|c|c|c|}
\hline \multirow{3}{*}{ District } & \multicolumn{8}{|c|}{ Yellow rice stem borer (individual/sample) and borer eggs (egg/sample) } \\
\hline & \multicolumn{2}{|c|}{ Nursery } & \multicolumn{2}{|c|}{ Seedling } & \multicolumn{2}{|c|}{ Vegetative } & \multicolumn{2}{|c|}{ Generative } \\
\hline & PBK & Egg & PBK & Egg & PBK & Egg & PBK & Egg \\
\hline Tempuran & 0.20 & 0.30 & 0.006 & 0.02 & 0.00 & 0.003 & 0.003 & 0.020 \\
\hline Tirtajaya & 0.31 & 0.82 & 0.003 & 0.00 & 0.06 & 0.020 & 0.013 & 0.013 \\
\hline
\end{tabular}

Remarks: PBK $=$ Yellow rice stem borer. The nursery stage of the individual/20 shoots and the seedling, vegetative and generative stages of the individual/50 clumps. 
time of the moth trap, which is 4 days after the flight of the moth, both in the vegetative and generative stage (Baehaki, 2013). The control effort carried out by farmers is the use of dimehipo and fipronil insecticides.

The intensity of $C$. medinalis attacks at Tempuran District in the seedling stage was $5.30 \%$, the vegetative stage was $5.43 \%$, and the generative stage was $4.80 \%$. At Tirtajaya District, the intensity of C. medinalis attacks found in the seedling stage was $7.88 \%$, the vegetative stage was $8.20 \%$ and the generative stage was $4.10 \%$ (Table 6 ). The intensity of the attacks is below the economic threshold. The economic threshold of C. medinalis was $15 \%$ in the vegetative stageand 5\% in the generative stage (Untung, 1984 cit. Anwar, 1989). Farmers use cypermethrin or permethrin to control C. medinalis. The intensity of M. separata attacks was only $0.13 \%$ in the generative stage at Tempuran District and $1.05 \%$ at Tirtajaya District (Table 6). The intensity of $M$. separata attacks is relatively low. There were no intensive control efforts made by farmers because $M$. separata attacks were low.

Ricefield Rat. Ricefield rat ( $R$. argentiventer) is one of important rice pests because it can cause high damage and loss. Ricefield rat is a pest that can attack all stages of the growth of wetland rice plantation. At Tempuran District, ricefield rat attack was found in all stages of rice growth up to $5.50 \%$ in the nursery, $3.96 \%$ in the seedling stage, $9.05 \%$ in the vegetative stage, and $9.20 \%$ in the generative stage. Ricefield rat attack at Tirtajaya District in the vegetative stage was $0.76 \%$ and the generative stage was $1.00 \%$ (Table 7 ). The highest attack intensity was found in the generative stage. This was due to the optimal growth of plants in the generative stage, which causes relatively stable environmental conditions. The volatile scent on the full stage of rice plants affects the breeding behavior of ricefield rats (Siregar, 2018). Female ratsfound in the vegetative stage were generally mature and ready to mate and those found in the generative stagegenerally had offspring (Sudarmadji, 2007).

The control of the ricefield rat at the nursery was using the installation of plastic around the seedbed and using electric shock. Efforts to control in the seedlings stage are still using electric shock. Electric shock installation has been banned by the government, but still used by farmers because it is considered effective to control ricefield rats.

The control of the ricefield rat was conducted in the vegetative stage using kalagumarang, oil and diesel applications, and electric shock. Kalagumarang is only carried out at Tirtajaya District. Kalagumarang is an activity carried out by several farmers to eradicate rats. Rat's nest will be penetrated with water mixed with gasoline then the rats would come out of the nest and beaten directly by farmers using blocks. Kalagumarang is effective in eradicating ricefield rats. Oil and diesel applications are not effective on wetland because oil and diesel content would run off by irrigation channels.

Table 6. The intensity of pest attack during the growth stage of wetland rice plantation at Tempuran and Tirtajaya District, Karawang, October 2018-April 2019

\begin{tabular}{|c|c|c|c|c|c|c|c|}
\hline \multirow{3}{*}{ District } & \multicolumn{7}{|c|}{ The intensity of pest attacks (\%) at each growth stage } \\
\hline & \multicolumn{2}{|c|}{ Nursery } & \multicolumn{2}{|c|}{ Vegetative } & \multicolumn{3}{|c|}{ Generative } \\
\hline & Bo & RLr & Bo & RLr & Bo & $\mathrm{RLr}$ & $\mathrm{Aw}$ \\
\hline Tempuran & 12.35 & 5.30 & 5.53 & 5.43 & 4.45 & 4.80 & 0.13 \\
\hline Tirtajaya & 16.90 & 7.88 & 6.90 & 8.20 & 6.25 & 4.10 & 1.05 \\
\hline
\end{tabular}

Remarks: Bo = Borer, RLr= rice leafroller, and Aw = Armyworm. Nursery stage 20 shoots (individual/shoot), seedling, vegetative, and generative stage 50 clumps (individual/clump).

Table 7. The intensity of ricefield rat attack during the growth stage of wetland rice plantation at Tempuran and Tirtajaya District, Karawang, October 2018-April 2019

\begin{tabular}{|c|c|c|c|c|}
\hline \multirow{2}{*}{ District } & \multicolumn{4}{|c|}{ The intensity of ricefield rat $(\%)$ in each growth stage } \\
\hline & Nursery & Seedling & Vegetative & Generative \\
\hline Tempuran & 5.50 & 3.96 & 9.05 & 9.20 \\
\hline Tirtajaya & 0.00 & 0.00 & 0.67 & 1.00 \\
\hline
\end{tabular}

Remarks: Nursery stage 20 shoots/location, seedlings, vegetative, and generative stage 50 clumps/location. 
There are no intensive control efforts made by farmers in the generative stage. the controls by farmers are not recommended by the Agricultural Extension Worker or the Department of Agriculture. The Agricultural Extension Worker assistance practice has not been carried out on a scheduled basis hence resulted in the farmers still use the old patterns or habits in controlling pests and diseases and not according to the recommended technical guidelines.

\section{Natural Enemies in “Upsus” Wetland Rice Plantation}

The existence of a natural enemy in a wetland rice plantation area could reduce the rate of a pest population in a wetland rice plantation. Natural enemies were observed on direct observation is pest predators and not all arthropods were observed. Observation of natural enemies, pests, and diseases is carried out on the same sample. The types of major natural enemies found were Paederus sp., Cyrtorhinus sp., Tetragnatha sp. dan Lycosa pseudoannulata. Direct assessment of natural enemies was performed by observing the type and number of natural enemies in the samples. The number of natural enemies found at the observation site waslow due to the use of pesticides by farmers. The higher population density of natural enemies was in the generative stage. Plant growth in the generative stage was optimal, plant canopy begins to dense and many alternative hosts are available. Alternative hosts are the shelter for natural enemies from pesticides, other predatory insects, or when environmental conditions are unstable. Alternative hosts are important components of agroecosystems. They positively affect the biology/dynamics of natural enemies as a shelter for natural enemies when environmental conditions are not unhabitable (Wijayanti, 2011).

Paederus sp. was a natural enemy found in all stages of wetland rice plant growth. At Tempuran District, the population density of Paederus sp. in the nursery stage was 0.050 individual/shoot, the seedling stage was 0.010 individual/clump, the vegetative stage was 0.090 individual/clump, and the generative stage was 0.360 individual/clump. At Tirtajaya District, in the nursery stagewas found $0.230 \mathrm{individual} / \mathrm{shoot}$, the seedling stage was 0.013 individual/clump, the vegetative stage was 0.250 individual/clump, and the generative stage was 0.450 individual/clump (Table 8 ). The main prey of Paederus sp. was brown planthopper. Within a day, Paederus sp. could prey 4.9 brown planthoppers (Killin, 1994 cit. Santosa, 2007). The existence of Paederus sp. on plantations could reduce the level of the brown planthopper population.

At Tempuran District, Cyrtorhinus sp. found in the nursery was 0.008 individual/shoot, in the seedling stage was none, in the vegetative stage was 0.003 individual/clump, and in the generative stage was 0.040 individual/clump. At Tirtajaya District, Cyrtorhinus sp. found in the nursery stage was 0.440 individual/shoot, in the seedling stage was 0.006 individual/clump, in the vegetative stage was 0.020 individual/clump, and in the generative stage was 0.100 individual/clump (Table 8). Cyrtorhinus sp. was brown planthopper natural enemy. Besides adults and nymphs, Cyrtorhinussp. also preys on brown planthopper eggs. Within a day, Cyrtorhinus sp. able to prey 4.1 eggs (IRRI, 1978 cit. Santosa, 2007).

The population of Tetragnatha sp. At Tempuran Districtwas not found in the nursery and seedling stage but only found in the vegetative stage $(0.030$ individual/clump) and the generative stage (0.003 individual/clump).At Tirtajaya District, Tetragnatha sp. in the nursery stage was 0.025 individual/shoot, the seedling stage was 0.003 individual/clump, the vegetative stage was 0.060 individual/clump, and in the generative stage was 0.006 individual/clumps.

L. pseudoannulata is a natural enemy that preys on rice borer, rice leafroller, leafhoppers, and other pests. At Tempuran District, L. pseudoannulata population was not found in the nursery but was found in the seedling stage (0.03 individual/clump), in the vegetative stage (0.006 individual/clump), and the generative stage ( 0.03 individual/clump). At Tirtajaya District, the nursery was also not found, in the seedling stage was found 0.003 individual/clump, in the vegetative stage was 0.02 individual/clump, and the generative stage was 0.05 individual/clump (Table 8). The existence of natural enemies in plantations is beneficial to maintain the ecosystem stability of wetland rice. The natural enemy is a factor controlling the population in nature and also an abiotic factor that plays a major role in maintaining the balance of the ecosystem (Mahrub, 1999). 


\section{Plant Disease Severity in "Upsus" Wetland Rice}

Only the major diseases found that would be measured the disease incidence. The direct assessment revealed that the major diseases in "Upsus" wetland rice were bacterial leaf blight (X. oryzae pv. oryzae), blasts (P. grisea), and narrow brown spots (C. oryzae). The other diseases such as dwarf grass were not found. It was suspected that the population of brown planthopper found during direct assessment was low and was not carrying the virus causes grass dwarf.

Bacterial Leaf Blight Disease. Bacterial leaf blight is a disease caused by X. oryzae pv. oryzae and have general symptoms such as green leaves that dry out with curved leaf strands and followed by rolledleaf along the midrib (Semangun, 2008). The severity of bacterial leaf blight at Tempuran District in the nursery was $1.74 \%$, in the seedling stage was $2.18 \%$, in the vegetative stage was $2.81 \%$ and in the generative stage was $8.20 \%$. At Tirtajaya District, the severity of bacterial leaf blight in the nursery was $1.15 \%$, in the seedling stage was $1.31 \%$, in the vegetative stage was $2.45 \%$ and in the generative stage was $4.01 \%$ (Table 9). The lack of knowledge in distinguishing pests and disease symptoms resulting in miss applying pesticides. Some farmers are still not able to distinguish the symptoms of bacterial leaf blight attack and dead heart symptoms in the vegetative stage of planting thus insecticide was used to overcome the bacterial leaf blight. In the generative stage, the control was conducted using difenoconazole fungicide or bactericides combined with azoxystrobin fungicide.

Blast Disease. Blast is caused by P. grisea and show symptoms such as the formation of spots in funnel pointed tip leaves with a whitish-gray spot and have a reddish-brown edge. Spots on older leaves appear smaller and more rounded. Spots tend to accumulate at the base of the leaf blade. Blast disease can cause tip rot in the panicle stems (Semangun, 2008). P. grisea can infect all growth stages of wetland rice plantation. At the observation site, symptoms of blast disease were only found in the nursery stage with disease severity of $0.10 \%$ at Tempuran District and $0.64 \%$ at Tirtajaya District (Table 9). In the nursery, farmers only use urea mixed with an insecticide with the active ingredient of carbofuran resulting in the nursery has a high nitrogen content and triggers the presence of blast disease (Semangun, 2008).

Narrow Brown Spot Disease. Narrow brown spot is a disease caused by $C$. oryzae and is an endemic disease in Subang and Karawang areas. Symptoms of narrow brown spot disease could be identified with narrow spots on the leaves, reddishbrown color, and parallel to the midrib. When plants forming tillers the number of spots increases and when the plants begin to mature severe symptoms could be identified on the flag leaves (Semangun, 2008).

Table 8. The number of natural enemies was found during the growth stage of wetland rice at Tempuran and Tirtajaya District, Karawang, October 2018-April 2019

\begin{tabular}{|c|c|c|c|c|c|c|c|c|c|c|c|c|c|c|c|c|}
\hline \multirow{3}{*}{ District } & \multicolumn{16}{|c|}{ The population of natural enemies (individual/samples) at every stage of the growth of wetland rice } \\
\hline & \multicolumn{4}{|c|}{ Nursery } & \multicolumn{4}{|c|}{ Seedling } & \multicolumn{4}{|c|}{ Vegetative } & \multicolumn{4}{|c|}{ Generative } \\
\hline & $\mathrm{Pae}$ & Cir & Tet & Ly & $\mathrm{Pae}$ & Cir & Tet & Ly & Pae & Cir & Tet & Ly & $\mathrm{Pae}$ & Cir & Tet & Ly \\
\hline Temp & 0.05 & 0.008 & - & - & 0.01 & - & - & 0.03 & 0.09 & 0.003 & 0.03 & 0.006 & 0.40 & 0.04 & 0.003 & 0.03 \\
\hline Tirta & 0.23 & 0.44 & 0.02 & - & 0.01 & 0.006 & 0.003 & 0.003 & 0.25 & 0.02 & 0.06 & 0.02 & 0.45 & 0.10 & 0.006 & 0.05 \\
\hline
\end{tabular}

Remarks: Temp = Tempuran, Tirta = Tirtajaya. Pae =Paederus sp., Cyr =Cyrtorhinus sp., Tet = Tetragnatha sp., and Ly = Lycosa pseudoannulata. Nursery 20 shoots (individual/shoot), seedling, vegetative and generative stage 50 clumps (individual/clump).

Table 9. The severity of the disease was found during the growth stage of wetland rice at Tempuran and Tirtajaya District, Karawang, October 2018-April 2019

\begin{tabular}{|c|c|c|c|c|c|c|}
\hline \multirow{3}{*}{ District } & \multicolumn{6}{|c|}{ The severity of disease (\%) in each stage of the growth of the wetland rice } \\
\hline & \multicolumn{2}{|l|}{ Nursery } & \multirow{2}{*}{$\frac{\text { Seedling }}{\text { Bacterial leaf blight }}$} & \multirow{2}{*}{$\frac{\text { Vegetative }}{\text { Bacterial leaf blight }}$} & \multicolumn{2}{|c|}{ Generative } \\
\hline & Bacterial leaf blight & Blast & & & Bacterial leaf blight & Narrow brown spot \\
\hline Tempuran & 1.74 & 0.10 & 2.18 & 2.81 & 8.20 & 0.38 \\
\hline Tirtajaya & 1.15 & 0.64 & 1.31 & 2.45 & 4.01 & 0.48 \\
\hline
\end{tabular}

Remarks: Nursery stage 20 shoots (individual/shoot), seedling, vegetative, and generative stage 50 clumps (individual/clump). 
Symptoms of narrow brown spot disease at the observation site were only found in the generative stage with disease severity of $0.38 \%$ at Tempuran District and $0.48 \%$ at Tirtajaya District (Table 9). There were no control measures undertaken because of the attack was considered low.

\section{CONCLUSION}

The major pests found at the "Upsus" site were brown planthopper, rice bug, yellow rice stem borer, rice black bug, rice leafroller, armyworm, and ricefield rat. The pests found are quite diverse despite having a low population density. This is caused by the presence of natural enemies, the use of resistant varieties, fertilization, and cultivation techniques, weather factors (temperature, humidity, and rainfall), and the use of conventional pesticides. The intensity of the use of conventional pesticides by "Upsus" farmers is more than 10 times/planting season. The intensity of the attack found at the observation site came from yellow rice stem borer, rice leafroller, armyworm, and ricefield rat. Yellow rice stem borer attack in the seedling stage exceeds the economic threshold. Efforts to prevent the yellow rice stem borer attacks should begin in the nursery stage. The use of pesticides is scheduled to begin in the seedling stage. The use of pesticides does not eliminate the presence of natural enemies. Natural enemies were still found at the observation site despite having a low population density. Types of natural enemies found were Paederus sp., Cyrtorhinus sp., Tetragnatha sp., and L. pseudoannulata.

The major diseases found at the observation site were bacterial leaf blight, blast, and narrow brown spot. The severity of the disease found was low. The lacking ability of farmers to distinguish between symptoms of pests and diseases affects the use of pesticides following the intended purpose.The implementation of "Upsus" at the farm level was generally following Upsus technical guidelines, except for pest and disease control. Control efforts by "Upsus" farmers were not following the IPM concept that recommended by "Upsus". The attitude and actions of farmers in controlling pests and diseases were still influenced by basis factors according to habit. If the implementation of the "Upsus" program planned continuously, it is necessary to manage monitoring, counseling, and mentoring on a scheduled by Agricultural Extension Worker considering many varieties of pests and diseases were found at the "Upsus" location.

\section{LITERATURE CITED}

Afifah, L. 2019. Fluktuasi Populasi Serangga pada Lahan Persawahan Kecamatan Pangkalan Karawang: Indikator untuk Kesehatan Lingkungan. Jurnal Ilmu Dasar 20: 1-6.

Anwar, R. 1989. Pengamatan Hama-Hama Penting Tanaman Padi (Oryza sativa L.) di Wilayah Kerja Penyuluh Pertanian Kali Jati, Wilayah Kerja Balai Penyuluhan Pertanian Kali Jati Kabupaten Subang Provinsi Jawa Barat. Skripsi. Fakultas Pertanian. Institut Pertanian Bogor, Bogor. 62 p.

Aprizal. 2018. Intensitas Serangan Hama dan Patogen pada Agroekosistem Hidroponik Tanaman Padi dengan Berbagai Media Tanam. Jurnal Agrotek Tropika 6: 86 - 90.

Badan Penelitian dan Pengembangan Pertanian. 2009. Deskripsi Varietas Padi. Kementerian Pertanian, Jakarta. 105 p.

Badan Penelitian dan Pengembangan Pertanian. 2012. Mengenal Predator Utama pada Tanaman Padi. Kementerian Pertanian, Jakarta. 17 p.

Baehaki, S.E. 2013. Hama Penggerek Batang Padi dan Teknologi Pengendaliannya. Iptek Tanaman Pangan 8: 7-12.

Baehaki, S.E. \& M.J. Mejaya. 2014. Wereng Cokelat sebagai Hama Global Bernilai Ekonomi Tinggi dan Strategi Pengendaliannya. Iptek Tanaman Pangan 9: 2-5.

Baehaki, S.E. 2016. Resistensi Wereng Cokelat terhadap Insektisida yang Beredar di Sentra Produksi Padi. Penelitian Tanaman Pangan 35: $3-6$.

Direktorat Jenderal Tanaman Pangan. 2015. Pedoman Teknis GP-PTT Padi. Kementerian Pertanian, Jakarta. 100 p.

Direktorat Pupuk dan Pestisida. 2014. Petunjuk Pelaksanaan Penyusunan Rencana Defenitif Kelompok Tani (RDKK) Pupuk Bersubsidi. Kementerian Pertanian, Jakarta. 20 p.

Heinrichs, E.A., W. Katanyukul, K.A.N.M. Rezaul, \& B.C. Misra. 1986. Management of Insect Pests in Rainfed Lowland Rice. Progress in Rainfed Lowland Rice. International Rice Research Institute, Manila. 358 p. 
IRRI. 2005. Masalah Lapang Hama Penyakit Hara pada Padi. Cetakan ke 2. [Translated from Rice Knowledge Bank Version 2,2., translator: M. Syam, D. Wurjandari]. Pusat Penelitian dan Pengembangan Tanaman Pangan, Jakarta. 71 p.

IRRI. 2014. Standard Evaluation System (SES) for Rice. International Rice Research Institute, Los Banos. 58 p.

Kartohardjono, 2009. Hama Padi Potensial dan Pengendaliannya. Jurnal Balai Besar Penelitian Tanaman Padi 6: 405- 425.

Kementerian Pertanian. 2015. Peraturan Menteri Pertanian Republik Indonesia Nomor 3 Tahun 2015 tentang Pedoman Upaya Khusus, Peningkatan Produksi Padi, Jagung, Kedelai melalui Perbaikan Irigasi dan Sarana Pendukungnya. Kementerian Pertanian, Jakarta.

Kementerian Pertanian. 2017. Produksi, Luas Panen dan Produktivitas Padi di Indonesia 2013 - 2017. http://www.pertanian.go.id/ap_pages/ mod/datatp, modified 20/04/2017.

Mahrub, E. 1999. Kajian Keanekaragaman Artropoda pada Lahan Padi Sawah Tanpa Pestisida dan Manfaatnya dalam Pengendalian Hama Terpadu. Jurnal Perlindungan Tanaman Indonesia 5: 35-41.

Maulana,W., Suharto, \& Wagiana. 2017. Respon Beberapa Varietas Padi terhadap Serangan Hama Penggerek Batang Padi dan Walang Sangit. Agrovigor 10: 21-27.

Nurbaeti, B., A. Diratmaja, \& S. Putra. 2010. Hama Wereng Cokelat (Nilaparvatalugens Stal.) dan Pengendaliannya. Departemen Pertanian. Balai Pengkajian Teknologi Pertanian Jawa Barat, Lembang. $24 \mathrm{p}$.

Paendong, E., J. Pelealu, \& J. Rimbing. 2011. Penyebaran Hama Kepinding Tanah dan Musuh Alaminya pada Pertanaman Padi Sawah di Sulawesi Utara. Eugenia 17: 7-10.

Priyonugroho. 2014. Analisis Kebutuhan Air Irigasi (Studi Kasus pada Daerah Sungai Air Keban Kabupaten Empat Lawang). Jurnal Teknik Sipil dan Lingkungan 2: 457-470.
Putra, R. 2018. Hama dan Penyakit Tanaman Padi dan Deskripsi Padi Sawah. Balai Pengkajian Teknologi Pertanian Kepulauan Riau, Riau. 25 p.

Santosa. 2007. Peranan Musuh Alami Hama Utama Padi pada Ekosistem Sawah. Jurnal Inovasi Pertanian 6: 1-10.

Semangun, H. 2008. Penyakit-Penyakit Tanaman Pangan di Indonesia. Gadjah Mada University Press, Yogyakarta. 475 p.

Sianipar, M.S. 2018. Fluktuasi Populasi Serangga Hama Wereng Batang Coklat (Nilaparvata lugens Stal.) pada Lahan Padi Sawah Universtas Wiralodra, Desa Singaraja, Kecamatan Indramayu, Kabupaten Indramayu. Seminar Nasional Dies Natalies UNS ke 42. Vol. 2 (1).

Sipayung, R.E., S. F. Sitepu, \& F. Zahara. 2018. Evaluasi Serangan Tikus Sawah setelah Pelepasan Burung Hantu di Kabupaten Deli Serdang. Jurnal Agroteknologi Fakultas Pertanian Universitas Sumatera Utara 6: 345-355.

Siregar, M.H. 2018. Pola Pergerakan Tikus Sawah di Ekosistem Sawah Irigasi dan Kelemahan Utama dalam Tindakan Pengendaliannya. Thesis. Fakultas Pertanian. Institut Pertanian Bogor, Bogor. $48 \mathrm{p}$.

Sudarmadji. 2007. Karakteristik Perkembangbiakan Tikus Sawah pada Ekosistem Sawah Irigasi dan Implikasinya untuk Pengendalian. Penelitian Pertanian Tanaman Pangan 26: 93-99.

Tangkilisan, V.E., C.L. Salaki, M.F. Dien, \& E.R.M. Meray. 2013. Serangan Hama Putih Palsu (Cnaphalocrosis medinalis) pada Tanaman Padi Sawah di Kecamatan Ranoyapo Kabupaten Minahasa Selatan. Eugenia 19: 23-29.

Wijayanti, R. 2011. Manipulasi Habitat sebagai Solusi Terjadinya Outbreak Wereng Coklat. Jurnal Esakta 33: 35-42. 